\title{
SUPERMAKET DIVIDEND DISTRIBUTION POLICY
}

\author{
${ }^{123}$ Yusuf Wibisono, M.Sholihun, Nani Hanifah \\ Departement of Accountinng, STIE Widya Gama Lumajang ${ }^{1}$ \\ IAI Sunan Kalijogo Jabung Malang ${ }^{2}$ \\ IAIN Fattahul Muluk Papua ${ }^{3}$
}

Email: yusufwibisono1965@gmail.com

\section{A RT ICLE INFO}

Date of entry:

7 Oktober 2019

Revision Date:

23 November 2019

Date Received:

12 Desember 2019

\begin{abstract}
A B S T R A C T
This study aims to examine the development of the management of Lumajang Supermarkets Amanah Supermarkets, which was established in 2012 with its own capital and sell shares to the public as long as approximately seven can run well in the midst of business competition and can earn profits or profits stably, so as to divide dividends to shareholders. This research is a qualitative descriptive study. The data was obtained from the Lumajang Shirkah Amanah Self-Service report for the past three years. From the profits obtained, the management makes a policy of profit sharing through the General Meeting of Share Shares (GMS). The provisions include net profit before being distributed to shareholders, issued in advance by $25 \%$ for business development, $2.5 \%$ for managers, $2,5 \%$ for organizations, $2.5 \%$ for infaq/ zakat syirkah, and $1 \%$ for shareholder shopping rewards. Dividend distribution policy is influenced by several factors, including corporate liquidity, profitability and is supported by earnings stability.
\end{abstract}

Keywords: Management, Shares, Dividend

Cite this as: Wibisono, Y., Sholihun, M., Hanifah, N. (2020). SUPERMAKET DIVIDEND DISTRIBUTION POLICY. Assets : Jurnal Ilmiah Ilmu Akuntansi, Keuangan dan Pajak, 4(1), 8-15.

\section{INTRODUCTION}

Supermarkets Syirkah Amanah established in 2012 in the middle of the city of Lumajang. Because capital is limited, SupermarketSyirkah Amanah opens (sells) shares to the public. Shares sold are common Stock (Common Stock). With this common stock, if the company makes a profit, ordinary shareholders will get dividends at the end of the financial year. According to Umam and Sutanto (2017), shares are the right of a part of something to one's wealth. Shares are also interpreted as proof of ownership of the capital of a company that gives rights to the holders of the company's assets.

Irham Fahmi (2013) mentions only two stocks that are most commonly known in the capital market, namely Common Stock (securities) are securities sold by a company that explains the nominal value (rupiah, dollar, yen and so on, where the holder is given the right to attend RUPS (General Meeting of Shareholders) and EGMS (Extraordinary General Meeting of Shareholders) and have the right to determine whether to buy a rights issue (limited share sale), which 
subsequently will benefit in the form of dividends at the end of the year. special stock) is a securities sold by a company that explains the nominal value (rupiah, dollar, yen and so on) where the holder will get fixed income in the form of dividends to be received every quarter (quarterly) Investing in shares can have several benefits. Among the benefits that can be obtained by the Sahama owner is to get a dividend that will be given at the end of each year, obtain capital gains, i.e., profits, when the shares owned, are resold at a higher price, have voting rights for common stock shareholders (ordinary shares ). Based on observations, shareholders in Lumajang Amanah Supermarkets Supermarkets can feel some benefits, get dividends, get capital gainand has voting rights at the AGM held in each period. Furthermore, regarding the dividend distribution policy, According to Riyanto (2011), the definition of dividend policy is a policy that is concerned with determining the distribution of income (earnings) between users of income to be paid to shareholders as dividends or to be used in companies, which means that income must be planted within the company.

The dividend policy decided by the directors may decide that profits generated by the company at the end of the period are distributed to shareholders (dividends). But it can also be retained as an increase in company capital that will be used in activities, or investment in company development in the future. There are three choices in the dividend distribution policy for profits distributed to shareholders (dividends), profits are reused for activities and business expansion (retained earnings), profits are shared between dividends, and some are used for retained earnings.

Based on comparison with some previous studies, there are some similarities in looking at the factors that influence dividend distribution policies, such as liquidity factors, profitability factors, company growth, and so forth. But in the study of dividend distribution policy at the Amanah Syirkah Supermarkets, it is not only based on business interests, namely to get the maximum amount of dividends and capital gains, but there is another side to the dividend distribution policy, which is to provide dividend distribution specifically for infaq or zakat distributed to orphanages. The purpose of this research is to know business development, the application of dividend distribution policies, and factors that influence dividend distribution policies at supermarkets Syirkah Amanah Lumajang.

\section{METHODS}

This research is a qualitative descriptive study, where the researcher intends to analyze the data by describing or describing the data that has been collected as it is without intending to make conclusions that apply to the public or generalization. This research is sourced from two types of data, namely primary data and secondary data. Primary data obtained directly from the original source of the company or organization. The primary data of this study is based on documentation and the results of interviews with managersSupermarkets Syirkah Amanah Lumajang, While secondary data is data obtained indirectly by researchers, obtained through publications in various media. Secondary data was also obtained from literature studies, literature books that are related to the problem discussed.

The data collected in this study was obtained in several ways, including interviews, observations, and data from the documentation Interview (interview), which is a data collection technique with a question and answer process (dialog) to parties related to the object of research, so that the data obtained is appropriate or relevant to the discussion. In this study, the authors used unstructured interviews, i.e., interviews that were not directed to one interview guide or interviews that were conducted freely where the authors only used an outline of the problem to be asked. Observation, which is a data collection technique by directly observing the object of research, without any communication with the person concerned. Observations were made to observe and know business management and distribution of dividends at the Amanah Syirkah Supermarket Lumajang. Documentation, which is a data collection technique by collecting data that is already available. 
This is done by taking data obtained through documents, among others, in the form of data, archives, and images or other forms.

To analyze research data, the essay with the previous explanation, that this study is a qualitative descriptive study. Therefore the data analysis technique that will be used in this study is to use qualitative analysis-statistical analysis. The non-statistical analysis is often referred to as content analysis (content analysis), which includes descriptive analysis, critical, comparative, and synthesis.

\section{RESULTS AND DISCUSSION}

Supermarkets Syirkah Amanah opened a business service in the middle of the city on Jalan Diponegoro No. 26 Lumajang. The shopping business venture was pioneered by the Lumajang Branch Manager of Muhammadiyah (PCM). For the self-service operation, a large amount of capital is needed. While the financial condition of PCM and Lumajang Muhammadiyah Orphanage is inadequate. So it was decided to run the self-service business by selling shares to the public, especially members and sympathizers of Muhammadiyah. The share price per share is Rp. 200,000. Those who planted shares were 162 people and institutions. The lowest share value is $\mathrm{Rp}$. 200,000, and the highest is Rp. 500,000,000 - Of shares sold to the public and own capital calculated by the value of the shares, until the end of 2019, it reached Rp. 2,688,200. 000 -. Based on reports, the business of the Amanah Syirkah Amanah business has been running since 2012. In the development of the business experiencing fluctuations, even at the beginning of standing experienced severe marketing constraints, when faced with business competition with other retail stores that flourished in Lumajang, with prices competing for products and variety of goods according to the needs of buyers or consumers.

Time has proven that the Amanah Syirkah Supermarket can still exist today. In the course of its business ventures, the Amanah Syirkah Amanah in each period can generate profits or profits. From 2012 to 2018, profit or profit continued to increase, then in 2019, it decreased slightly, and in 2020 it increased again.

Table 3.1 List of Benefits of Amanah Syirkah Supermarkets

\begin{tabular}{cccc}
\hline No. & Period & Amount (Rp.) & Information \\
\hline 1 & $2012-2013$ & $83,983,920-$ & Ride \\
2 & $2013-2014$ & $90,973,481-$ & Ride \\
3 & $2014-2015$ & $111,804,980-$ & Ride \\
4 & $2015-2016$ & $119,382,353-$ & Ride \\
5 & $2016-2017$ & $141,781,746-$ & Ride \\
6 & $2017-2018$ & $168,353,461-$ & Ride \\
7 & $2018-2019$ & $146,024,998-$ & Down \\
8 & $2019-2020$ & $164,403,570-$ & Ride \\
\hline
\end{tabular}

Source: Processed from the report of the Amanah Syirkah Amanah Period 2019-2020

From the profits obtained from the Shirkah Amanah Supermarket, through a General Meeting of Shareholders (GMS), a policy is made for dividend distribution. Referring to the provisions of Article 71 paragraph (2) of Law Number 40 the Year 2007 concerning Limited Liability Companies, dividends that can be distributed to shareholders are the entire net profit after deducting the allowance for reserves unless otherwise stipulated in the General Meeting of Shareholders (GMS). By considering the viability and growth of the Shirkah Amanah Supermarkets business, then the profits or profits derived are not entirely divided as dividends, but part of the profits obtained are set aside for reinvestment or partly retained in retained earnings. In 
terms of dividend distribution in the Amanah Syirkah Supermarkets set aside $25 \%$ for "Business Development" in addition to being taken 2 .

In general, in the dividend distribution policy, it can be decided that the profits generated by the company at the end of the period are distributed to shareholders (dividends). But it can also be retained as an increase in company capital that will be used in activities, or investment in company development in the future. During the last three periods, the policy taken in dividend distribution was business development: $25 \%$, infaq or zaka: $2.5 \%$, manager: $2.5 \%$, PCM: $2.5 \%$, shareholder shopping reward: $1 \%$, shopper reward Most: Rp. 500,000, - shareholder's gift: Rp. 30,000 x 162 In the last period, the GMS could not be held in May 2020 because it was constrained by the Corona pandemic 19. The dividend distribution policy at the Amanah Syirkah Supermarkets was carried out the same as the dividend distribution policy of the previous year. So, in general, the Lumajang Shirkah Amanah Supermarkets business can develop smoothly, the business generates profits from year to year, even though the profits do not always increase every year. The homework (PR) for the manager of Lumajang Supermarkets Syirkah Amanah, there are at least two important things. First, strive to ensure that Lumajang Supermarkets from Lumajang Amanah can continue to grow in the midst of business competition with other retailers in Lumajang. Second, directly proportional to the first is to keep Lumajang Shirkah Amanah Supermarkets from not experiencing the risk of loss, especially to the point of being closed down, as many other retailers experience. In order to develop even better, Supermarkets Syirkah Amanah needs to implement a marketing strategy. One of the most popular recent marketing strategies is the "Marketing Mix." This marketing strategy is widely used to be able to maintain consumers by providing maximum satisfaction. So this marketing mix is classified into one marketing strategy. According to Alma (2015), the marketing mix is a combination that provides maximum results from the elements of the marketing mix. Consists of 4 elements, namely product, price, place, and promotion, known as $4 \mathrm{P}$. Thus, the marketing mix is a marketing strategy implemented using four important elements, namely product or service products, price, place, and promotion. The strategy is used in an integrated manner from all four elements. The first element concerns the products sold. Supermarkets from Lumajang Amanah Supermarkets Lumajang want products that are provided in addition to good quality to have more variations so that when consumers come, they don't come back because the needed goods are not available. If things can be fulfilled, they will be able to provide satisfaction to consumers. Otherwise, if it can't be fulfilled, it will make consumers disappointed, and they don't want to come back. The second element concerns the price of goods sold. As usual, consumers will be interested in buying certain goods determined by the price. So this price can be a benchmark for buying a product by comparing prices at other stores. So, it becomes important to determine a good price, the right price, even a competitive price, because the price is very influential on sales. Make no mistake in determining prices that make consumers not interested in buying. Complained by some consumers, the prices of certain goods are still less than the prices of the same goods elsewhere. The third element concerns place (Location). This element is the most beneficial because the location of the Amanah Syirkah Supermarket is quite strategic, namely on Jalan Diponegoro 26 Lumajang, the location in the heart of Lumajang, a lively atmosphere, because it is passed by many people. This element can influence potential customers, and consumers remain interested and easy to reach locations. The fourth element concerns promotion. In fact, promotion is an important medium for introducing shops and also products sold to the public. With a good promotion, it is expected that sales will also increase. In this case, the promotion has not been well developed.

In this era, marketing or promotional activities are actually easier to do. For example, store management can utilize social media through mobile phones and the internet, advertisements, sponsorship partnerships, and other promotional methods. Based on the marketing mix marketing strategy, Lumajang Amanah Supermarkets from Lumajang Trusty benefit from two elements, namely strategic place and competitive price, although sometimes it is cheaper and sometimes higher than other retailers. What felt needed to be developed extensively were two other elements, namely a product whose variations were incomplete according to the needs of consumers and 
promises that had not yet been touched, in the presentation of research data compiled from the last report of Lumajang Shirkah Supermarkets, namely the 2019-2020 period, which planted 162 registered people and institutions. The lowest share value is Rp. 200,000, and the highest is Rp. $500,000,000$ - The total value of shares sold to the public or from their own capital (calculated as share value) until the end of 2019, reaching Rp. 2.688.200.000, - From the capital turnover, Lumajang Amanah Syirkah Supermarkets managed to benefit every current period, from 20122013 to $2019-2020$.

The highest profit is obtained in the period of Rp. 168,353,461. 2017-2018. The lowest profit occurred at the start of the standing of Rp. 83,983,920. The total profit from the beginning up until now is recorded at Rp. 1.026.708.509, - As explained above, the shares sold at Lumajang Amanah Supermarkets are classified as common shares in which the sahama holders are given the right to attend the RUPS and EGM, and at the end of the year, they will get a share of the profits in the form of dividends. In the dividend distribution policy, it can indeed be decided that the profits generated by the company at the end of the period are distributed to shareholders (dividends). But it can also be retained as an increase in company capital that will be used in activities, or investment in company development in the future. In dividend distribution, if dividends are distributed to shareholders, it will reduce retained earnings and further reduce the total source of internal funding or internal financing. Conversely, if the company chooses to hold the profits obtained, then the ability to form internal funds will be even greater. And what should be taken into consideration is the survival and growth of the company. Then the profits or profits derived by the company, in general, do not have to be divided entirely as dividends because some of the profits earned by the company are set aside for reinvestment then the ability to form internal funds will be even greater. And what should be taken into consideration is the survival and growth of the company. Then the profits or profits derived by the company, in general, do not have to be divided entirely as dividends because some of the profits earned by the company are set aside for investment than the ability to form internal funds will be even greater. And what should be taken into consideration is the survival and growth of the company. Then the profits or profits derived by the company, in general, do not have to be divided entirely as dividends because some of the profits earned by the company are set aside for reinvestment.

The policy made in determining dividends at the Lumajang Shirkah Supermarket Supermarkets choose from three alternative options for profits distributed to shareholders (dividends), profits are reused for business activities and expansion (retained earnings), profits are shared between dividends, and some are used for retained earnings. The policy that was made turned out to prefer the third alternative, namely profits divided between dividends and partly used for retained earnings. So the form of dividend distribution policy appears as follows for business development: $25 \%$, Infaq or zaka: $2.5 \%$, managers: $2.5 \%$, PCM: $2.5 \%$, shareholder shopping rewards: $1 \%$, most shopper rewards: Rp. 500,000, - shareholder's gift: Rp. 30,000 x 162. The dividend distribution policy made through the General Shareholders Meeting of Lumajang Shirkah Amanah Supermarkets appears to be the largest percentage for business development at $25 \%$. Interestingly, the dividend distribution policy does not only consider business interests, but there are socioreligious considerations so that the distribution of dividends is allocated an infaq or zakat fund of $2.5 \%$, which is channeled through the Lumajang Muhammadiyah Orphanage. This is in accordance with the motto of the Supermarkets Syirkah Amanah "Shopping with charity." Such a policy is legitimate. Because in practice, not all profits generated by the company are distributed all into dividends. And regarding the size of the dividend to be distributed to shareholders depends on the policy of each company.

The legal basis that refers to the provisions of Article 71 paragraph (2) of Law Number 40 the Year 2007 concerning Limited Liability Companies also provides allowance on the distribution of dividends. At the same time, dividends that can be distributed to shareholders are the entire net profit after deducting the allowance for reserves unless determined otherwise in the General Meeting of Shareholders (GMS). Of the dividend distribution portion, other than for business 
development, 25\%, which can be a large portion, is the Lumajang Muhammadiyah Orphanage, because the Lumajang Muhammadiyah Orphanage is listed as one of the shareholders with the highest nominal value of Rp. 500,000,000. It still gets additional from the infaq or zakat portion of $2.5 \%$. The following portion is what was received by Lumajang PCM because PCM Lumajang is listed as one of the shareholders with the second-highest nominal value of Rp. 100,000,000 and still get an additional $2.5 \%$ of the shares. After that, it shifts to the portion of individual or institutional shares, with nominal shares starting at Rp. 40,000,000 to the smallest share of Rp. 200,000

Referring to some literature, it can be seen that there are factors that influence policy in the dividend distribution. Relevant to this discussion will be divided into two factors, namely, internal factors and external factors. Internal factors include but not limited to company liquidity, profitability, and earnings stability. At the same time, external factors are focused on the existence of legal regulations or laws and regulations. According to M. Manullang (2016), liquidity is the ability of a company to pay financial obligations that must be fulfilled (which is short term). Among them are paying debts that are due, paying labor costs, paying accounts, paying taxes, and others. The liquidity position of a company is very influential in dividend policy-making, the more smooth the company's liquidity, the greater the company's ability to distribute dividends. And vice versa, There are several types of liquid instruments, including cash, accounts receivable (account receivable), merchandise, and securities.

While profitability is the company's ability to generate profits, business businesses that can earn profits (high), then the company is considered successful in running a business and can create internal funding for the company itself. If so, then the company will use the profits to be distributed to the owners as dividends and partly retained into retained earnings. Seen from this point of view, these two internal factors, the Lumajang Supermarkets of Lumajang Supermarkets are quite good liquidity and profitability so that it has a very positive effect on the policymakingpolicymaking of dividend distribution which is decided through the GMS. What's more, it is supported by profit stability. Business ventures that generate stable profits in each period, the management and shareholders will easily predict the size of the profit that will be generated in the coming period. From there, the planning regarding sources of funds and their use will become more directed and can be understood by all shareholders. Including the policy of dividend distribution, the size of the dividend to be received by shareholders can be predicted, even if it can increase.

Profits or profits obtained from the Amanah Syirkah Supermarkets generally appear to be quite stable and almost always increase. From the report data, it can be seen the development and stability of its profits from the period 2012-2013 to the period 2019-2020. 2012-2013 Period: Rp. 83,983,920, period 2013-2014: Rp. 90,973,481, -, period 2014-2015: Rp. 111,804,980, 2015-2016 period: Rp. 119,382,353, -, 2016-2017 period: Rp. 141,781,746, -, period 2017-2018: Rp. 168,353,461, -, period 2018-2019: Rp. 146,024,998, - for the period 2019-2020: Rp. 164,403,570.

Because the stability of earnings at Lumajang Amanah Syirkah Supermarkets is sufficiently maintained, so it has a very positive influence on policymakingpolicymaking in dividend distribution, the shareholders have been able to calculate the size of the dividends themselves after the GMS is held. For external factors, it can only be seen from one factor, namely legal and statutory factors. Relevant to this, which can be underlined, in accordance with applicable laws and regulations, the company does not necessarily immediately distribute dividends as desired. There are legal, regulatory mechanisms that limit company dividend policies. In this case, there is a rule that dividends are paid from profits, both the current year's net income and last year's net income (retained earnings).

In addition, the distribution of dividends can refer to several related regulations, including regulations regarding the net income that the distribution of dividends that can be paid is dividends derived from net income for the current period or the previous year's period (retained earnings). 
Regulations are prohibiting capital reduction. In this regulation, the point is to protect creditors (corporate loan providers). You do this by prohibiting the distribution of dividends that reduce capital. The intention is to pay dividends with capital to divide the company's capital. You are not sharing the company's net profit. Bankruptcy regulations. In this rule, it is determined that there is a prohibition on paying dividends when a company is declared bankrupt by the Court. Because, if the dividend is distributed when the company is declared bankrupt, that means distributing company assets to shareholders. Which, in fact, is the property or right of the company's lenders. Etc. Of the three points, which are in accordance with the conditions of Lumajang Supermarkets, the Lumah Amanah supermarket is the first point that the distribution of dividends that can be paid is dividends from the net profit of the current period.

\section{CONCLUSION}

Based on the results of the research that has been done and the discussion that has been explained, then in this study, it can be drawn several conclusions, in general, the development of Lumajang Supermarkets business can run smoothly, the business generates profits from year to year, although profits do not always increase every year. The policy made in determining dividends in the Lumajang Shirkah Amanah Supermarkets chose from three alternative options, namely profits distributed to shareholders (dividends), profits were reused for activities and business expansion (retained earnings), profits are divided between dividends and part of it is used for retained earnings. The policy that was made turned out to prefer the third alternative, namely profits divided between dividends and partly used for retained earnings risk funding, by preparing a reserve fund (reserve).

There are a number of factors that influence policy in the dividend distribution. In simple terms, there are two factors, namely internal and external factors. Among internal factors are company liquidity, profitability, and earnings stability. Seen from this point of view, Lumajang Supermarkets of Amanah Lumajang's liquidity and profitability is quite good, so that it has a very positive effect on the policy-making of dividend distribution, which is decided through the GMS. What's more, it is supported by fairly good profit stability and increasing every period. While external factors related to legal regulations and legislation.

Relevant to the results of research and discussion, it is necessary to submit some suggestions as follows for the manager of the Lumajang Shirkah Amanah Supermarket, the manager needs to apply Better development requires a marketing mix strategy, which is a marketing strategy that is implemented using four important elements (4P), namely product, price, place, and promotion. The strategy is used in an integrated manner from all four elements. And now it's $7 \mathrm{P}$, plus three more elements of people, physical evidence and process, like the wishes and expectations of shareholders, whatever form of business competition they face, Lumajang Amanah Supermarkets can continue to grow and succeed in increasing profits, thereby providing added value to the distribution of dividends to be received by shareholders. Strived stability maintained profits and not down. Maintaining liquidity and profitability, shareholders can better support the management of the Amanah Syirkah Supermarkets,

\section{REFERENCE}

Alma, B. (2015). Introduction to Business, ALFABETA, Bandung

Fahmi, I. (2013). Share and Bond Secrets, Unlimited Profit Strategy, ALFA BETA, Bandung

Fahmi, I. (2018). Introduction to the Indonesian Economy, Theory, Concepts and Reality, ALFABETA, Bandung

Husnan, S. (2012). Fundamentals of Financial Management, BPFE, Yogyakarta.

Husnan, S. (1998). Financial Management Theory and Application. BPFE. Yogyakarta.

Manullang, M. (2016). Introduction to Business, Indomedia Pustaka, Yogyakarta 
Riyanto, B. (2011). Fundamentals of Company Spending. BPFE. Yogyakarta.

Umam, K. \& Sutanto, H. (2017). Investment Management, CV. Pustaka Setia, Bandung

Law Number 40 of 2007

Constitution Nomor 362008

https://kumparan.com/wartabromo/bupati-lumajang-indomaret-dan-alfamart-jangan-buka-lagi.

Accessed Date. February 20, 2020

https://www.neliti.com/publications/77194/the influence of-tructure-ownership-to-policy-dividenon-company-manufacturing. Accessed Date. February 24, 2020

https://ojs.unud.ac.id/index.php/Management/article/view/14595. Accessed Date. February 24, 2020

http://www.journal.ubaya.ac.id/index.php/jimus/article/view/643. Accessed Date. February 24, 2020

https://mikroskil.ac.id/ejurnal/index.php/jwem/article/view/276. Accessed Date. February 24, 2020 https://scholar.google.co.id/scholar?start=10\&q=policy+dividing+dividen\&hl=en\&as_sdt=0,5.

Accessed Date.February 24, 2020 